\title{
Remarkable invasion of San Francisco Bay (California, USA) by the Asian clam Potamocorbula amurensis. II. Displacement of a former community
}

\author{
Frederic H. Nichols, Janet K. Thompson, Laurence E. Schemel \\ Water Resources Division, U.S. Geological Survey, 345 Middlefield Road (MS-496), Menlo Park, California 94025, USA
}

\begin{abstract}
Long-term macrobenthic sampling at a site in northern San Francisco Bay has provided an unusual opportunity for documenting the time course of an invasion by a recently introduced Asian clam Potamocorbula amurensis. Between 1977, when sampling began, and 1986, when the new clam was first discovered, the benthic community varied predictably in response to river inflow. During years of normal or high river inflow, the community consisted of a few brackish or freshwater species. During prolonged periods of low river inflow, the number of species doubled as estuarine species (e.g. Mya arenaria) migrated up the estuary. In June 1987, at the beginning of the longest dry period in recent decades, large numbers ( $>12000 \mathrm{~m}^{-2}$ ) of juvenile $P$. amurensis were discovered at the site. By midsummer 1988 the new clam predominated $(>95 \%)$ in both total number of individuals and biomass, and the expected dry-period estuarine species did not become re-established. The rapid rise of $P$. amurensis to numerical dominance throughout the region of the original introduction was probably facilitated by the fact that this region of the bay had been rendered nearly depauperate by a major flood in early 1986. Once introduced, the clam had sufficient time ( $>1 \mathrm{yr}$ ) to become well established before the salinity regime was appropriate for the return of the estuarine species. Subsequently, the new clam was apparently able to prevent the return of the dry-period community. Its ability to live in low salinity water $(<1 \%$ ) suggests that $P$. amurensis may not be displaced with the return of normal winter river flow and, therefore, may have permanently changed benthic community dynamics in this region of San Francisco Bay.
\end{abstract}

\section{INTRODUCTION}

The explosive population growth and spread of the euryhaline Asian corbulid clam Potamocorbula amurensis in northern San Francisco Bay soon after its arrival in 1986 (Carlton et al. 1990) raises fundamental questions: What were the conditions at the initial invasion site that permitted the invading species to become successfully established? What has been the effect of the invasion on the pre-existing community?

Detailed analyses of species invasions (e.g. Elton 1958, Mooney \& Drake 1986, Drake et al. 1989) suggest that, while the success of any given species introduction is not very predictable (Simberloff 1986), the important factors to be considered are the characteristics of that species, the availability of suitable habitat, and the nature of the community present in the invaded area. Our early detection of the invasion of San Fran- cisco Bay by Potamocorbula amurensis allows us to examine these factors.

Our study of this invasion has greatly benefited from the fact that the initial colonization occurred in Suisun Bay (Fig. 1), a region of San Francisco Bay that has been the focus of routine water column and sediment sampling (including quantitative macrobenthos sampling) since 1977. This is also the region of the estuary where the clam's influence on the existing benthic community has been most marked. The data from the long-term sampling effort provided us the opportunity to study benthic community dynamics both before and after the introduction of Potamocorbula amurensis, and to examine the circumstances under which the new species thrived.

The first purpose of this report is to describe the season-to-season and year-to-year patterns of variation in community structure that were characteristic of the 


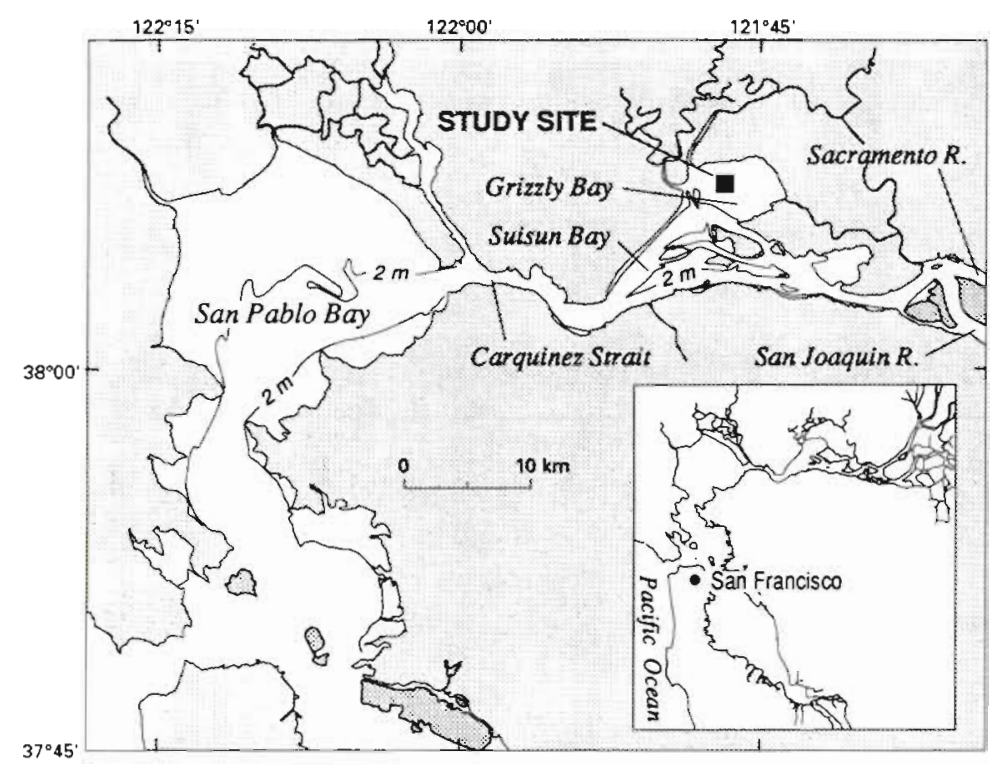

Fig. 1. Northern San Francisco Bay estuary, with location of the DWR/REM sampling area in Grizzly Bay

Suisun Bay site prior to the introduction of Potamocorbula amurensis. The second purpose is to document the change in these patterns that have occurred since the introduction. We will suggest that the timing of the initial introduction was probably fortuitous with regard to natural habitat disturbance; that is, the new clam was able to colonize underexploited habitat. The subsequent failure of the previously prominent species to recolonize the study area is probably a result of the presence of the new species.

\section{STUDY SITE AND METHODS}

Suisun Bay, an embayment located near the mouths of the 2 major rivers that flow into San Francisco Bay, the Sacramento and San Joaquin Rivers (Fig. 1), has been the focus of diverse scientific investigations (e.g. Cloern \& Nichols 1985). Thus, many aspects of the physics, chemistry and biology of this region are well understood. Suisun Bay is inundated by freshwater during winter periods of high river inflows (typically 1000 to $10000 \mathrm{~m}^{3} \mathrm{~s}^{-1}$ ). During the summer period of low river flow (100 to $300 \mathrm{~m}^{3} \mathrm{~s}^{-1}$ ) salinity increases to ca $10 \%$, although there is considerable year-to-year variation depending on the amount of precipitation during the previous winter As can be seen from the monthly means of river inflow (Fig. 2), extreme deviations from the long-term average are the rule rather than the exception.

Grizzly Bay (Fig. 1), the location of our investigation, is a shallow $(<2 \mathrm{~m}$ water depth at MLLW), muddy $(>80 \%$ silt and clay) embayment of Suisun Bay. Most of the benthic data from Grizzly Bay prior to the introduction of Potamocorbula amurensis come from a con- tinuing California Department of Water Resources (DWR) monitoring program at DWR Site D7 that included benthic sampling twice a year between 1977 and mid-1980, then at monthly intervals since mid1980 (see California Department of Water Resources 1989 for the most recent annual summaryl. These data are hereafter referred to as the DWR data. As part of a bay-wide Regional Effects Monitoring Program (REM; Schemel et al. 1988, 1990), additional benthic invertebrate samples were collected nearby at REM site GB (ca $0.5 \mathrm{~km}$ distant from the DWR-D7 site in the same water depth and sediment type) in September 1986 and at ca 2 mo intervals from March 1987 to November 1988. These data are hereafter referred to as the REM data.

The benthic macroinvertebrates in the DWR and REM sampling programs were collected using slightly different methods: the DWR investigators collected 3 samples on each date with a $0.053 \mathrm{~m}^{2}$ Ponar grab

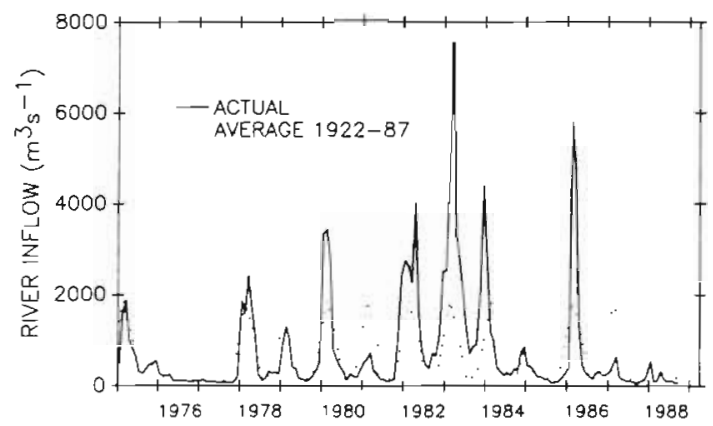

Fig. 2. Monthly mean river inflow into San Francisco Bay from the Sacramento/San Joaquin River system during the period 1975 to 1988, and mean monthly unflow based on the 1922 to 1987 period of inflow records. River inflow data provided by Californa Department of Water Resources (Dayflow Program. unpubl.) 
sampler and washed them on a $0.595 \mathrm{~mm}$ screen, whereas the REM investigators collected 5 samples with a $0.05 \mathrm{~m}$ van Veen grab sampler and washed them on a $0.5 \mathrm{~mm}$ screen. Because of the differences in methodology, we present the data from the 2 programs separately.

In our analyses we have used the mean abundance (the average from 3 or 5 replicates) on each sampling date for each species, with 2 exceptions. Because the identifications of species within the oligochaete family Tubificidae and within the amphipod genus Corophium have been inconsistent over time, we lumped the species within each of these 2 groups for purposes of tallying the total number of taxa present on each sampling date. Biomass (wet weight, with shells, blotted for $10 \mathrm{~min}$ ) changes at the REM site were determined for the mollusks, the faunal group that overwhelmingly dominates the biomass in Suisun Bay (Thompson \& Nichols 1981).

\section{RESULTS}

\section{Pre-introduction conditions}

The DWR data collected at the Grizzly Bay site since 1977 demonstrate that benthic community species composition and abundance markedly change from year to year. For example, while the number of species varied between 3 and 7 for most of the period, the number approximately doubled during the second year of prolonged periods of reduced freshwater inflow, e.g. 1977 and 1985 (Fig. 3a). As reported earlier (Nichols 1985), the additional species in Grizzly Bay during the 1977 dry period included the clam Mya arenaria, the amphipods Corophium acherusicum and Ampelisca abdita, and the polychaete Streblospio benedicti. $M$. arenaria, a Corophium species, and $A$, abdita were also predominant in 1985. These species are usually restricted to higher-salinity regions of the estuary west of Carquinez Strait (e.g. San Pablo Bay; Fig. 1). During prolonged dry periods, however, their larvae are presumably carried upstream to Suisun Bay in the saline bottom currents generated by river-induced gravitational circulation (Nichols 1985). Hereafter, we refer to this species group as the dry-period community and use $M$. arenaria as a representative species for purposes of our analysis.

The total number of individuals at the Grizzly Bay site has also varied markedly from year to year, with intermittent peaks of high abundance (Fig. 3b). As mentioned, the abundance peak of 1977 comprised the various species of the dry-period community. In contrast, abundance peaks during the summers of 1980 and 1982 through 1984 represented freshwater species
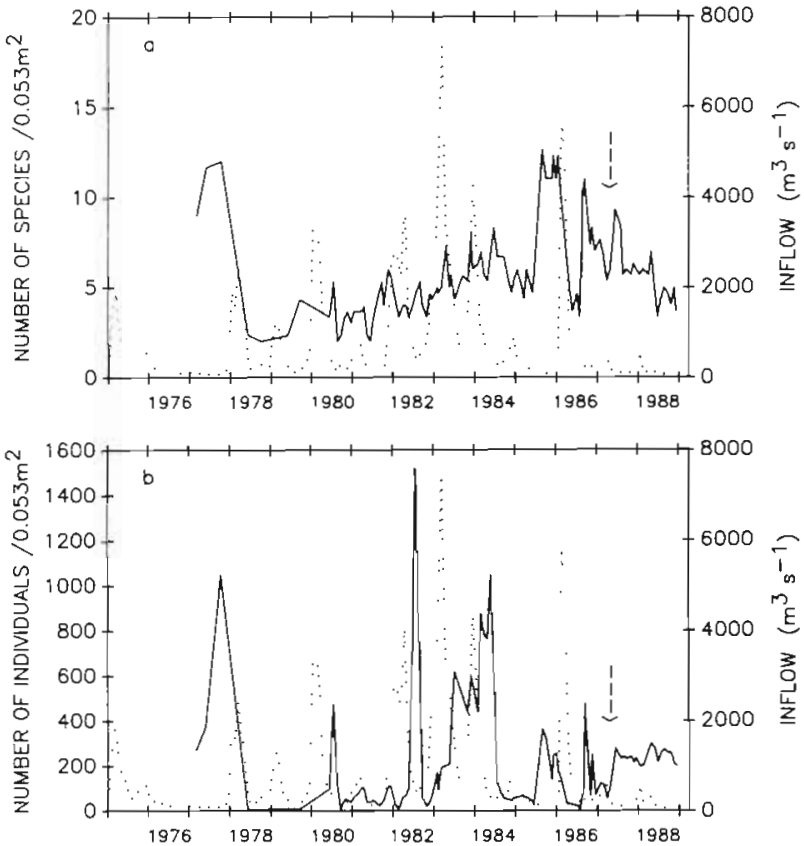

Fig. 3. (a) Mean number of species at the DWR site (continuous line) and monthly mean river inflow (dotted line). (b) Mean number of individuals of all species combined (continuous line) and monthly mean river inflow (dotted line). Arrows indicate the arrival time of Potamocorbula amurensis at the site

that arrived following flood events; the numerically dominant species were the oligochaete Limnodrilus hoffmeisteri in 1980, the amphipod Corophium stimpsoni in 1982, C. stimpsoni and L. hoffmeisteri in 1983, and $C$. stimpsoni and the freshwater mollusk Corbicula fluminea in 1984. The abundance peak in autumn of 1986 was largely due to highly patchy occurrences (e.g. 289,12 , and 914 individuals in the 3 DWR samples from September) of the barnacle Balanus improvisus attached to shell fragments, pieces of wood, and other debris that were probably transported to the site during the flood event earlier that year.

The DWR data collected through 1986 confirm the earlier prediction (Nichols 1985) that species of the dryperiod community will appear after extended periods of low river inflow. Between 1976 and 1988 there were 4 periods $(1976 / 77,1980 / 81,1984 / 85,1986 / 88)$ of unusually low flows when monthly mean river inflow was less than $1000 \mathrm{~m}^{3} \mathrm{~s}^{-1}$ for a period exceeding $1 \mathrm{yr}$ (Fig. 2). During the first three of these periods the population of Mya arenaria (our representative species for the dry-period community) reached peak abundance at the end of the second summer (Fig. 4), presumably from larvae spawned in late spring or early summer (e.g. Rosenblum \& Niesen 1985) by populations west of Carquinez Strait. Further, peak abundance of $M$. arenaria during each episode prior to the arrival of Potamocorbula amurensis in 1987 was, at least in part, 


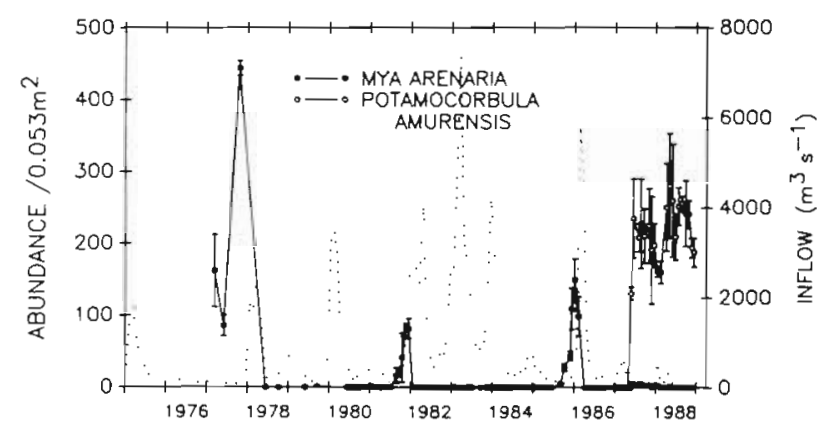

Fig. 4. Mya arenaria and Potamocorbula amurensis (data from California Department of Water Resources), with river inflow (dotted line)

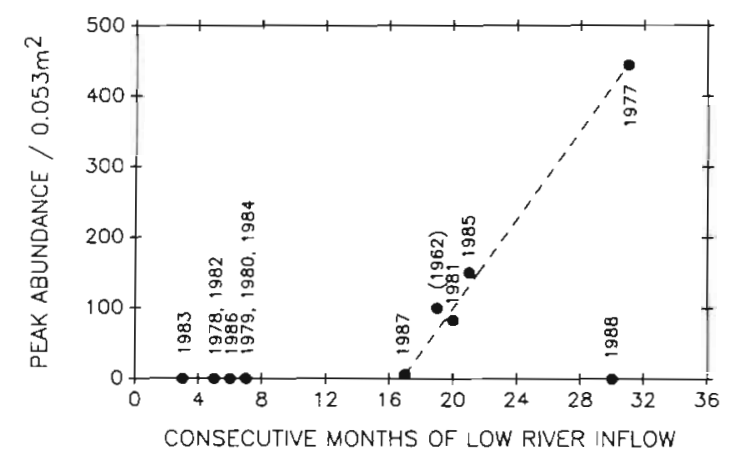

Fig. 5. Mya arenaria. Maximum mean abundance at the Grizzly Bay site during each year between 1977 and 1988 in relation to number of consecutive months of low $\left(<1000 \mathrm{~m}^{3}\right.$ $\mathrm{s}^{-1}$ ) river inflow, and a least-squares regression line for the 1987, 1981, 1985, and 1977 (pre-Potamocorbula amurensis) data. The 1962 data point, not included in the regression, is an average abundance from semi-quantitative samples collected from 2 Suisun Bay channel locations (Storrs et al. 1963, Stns 1 and 2)

related to the duration of the low-inflow period. That is, $M$. arenaria appeared at the study site only after a period of low river inflow that exceeded $16 \mathrm{mo}$, with peak abundance during any given year increasing with duration of the low inflow period (Fig. 5). Ampelisca abdita and Streblospio benedicti similarly were found only during the 1977,1981, and 1985 dry periods, and Macoma balthica was common (more than 1 or 2 ind. sample ${ }^{-1}$ ) only during those same years. This finding explains the observation that sustained peaks in the number of species occurred only during the latter part of the 2 longest dry periods prior to the arrival of Potamocorbula amurensis (1977 and 1985; Fig. 3a), and suggests that the successful establishment of the dryperiod community requires a period of low river inflow exceeding $16 \mathrm{mo}$.

\section{Post-introduction changes}

The arrival of Potamocorbula amurensis disrupted these well-established benthic community patterns.
The disruption was most apparent in the failure of the dry-period community to become re-established during the most recent and greatly prolonged dry period, e.g. as seen in the failure during 1988 of the simple relationship between dry-period community abundance and duration of the low-inflow period in 1988 (Fig. 5). With the exception of a few juveniles, the species of the dryperiod community have not been seen at these study sites since 1985.

As described in Carlton et al. (1990), Potamocorbula amurensis was first detected in Suisun Bay in October 1986. This species first appeared at the Grizzly Bay sampling site as 2 very small juveniles in the REM samples on 19 March 1987, the vanguard of a major recruitment event that reached its peak of 870 ind. per grab sample ( $\mathrm{SD}=340$; mean shell length $1.7 \mathrm{~mm}$ ) on 3 June 1987 (Fig. 6a). P. amurensis, first seen in the DWR samples on 20 May 1987 with an mean abundance per grab sample of $130(\mathrm{SD}=9)$ small individuals, reached a peak abundance of $235(\mathrm{SD}=55)$ in DWR samples on 9 June 1987 (Fig. 6a). We assume that the difference between the DWR and REM estimates of early peak abundance in the sampling area was a result of the slightly different location of the sampling sites and the larger screen mesh size used in the DWR program. Between June 1987 and January 1988 mean P. amurensis abundance in the REM samples had decreased to about 170 ind. per sample, and average shell length had increased from 1.7 to $5.8 \mathrm{~mm}$. In March $1988 \mathrm{ca} 100$ newly settled clams (mean shell length $1.6 \mathrm{~mm}$ ) appeared in the REM samples, and by the end of 1988 there were about 200 individuals of mixed sizes in the samples (Fig. 6a). This population density persisted into 1989 .

Since late 1986, both the number of species (Fig. 6b) and the number of individuals of species other than Potamocorbula amurensis (Fig. 6c) have gradually declined (slopes of least squares regression lines significantly different from zero; $\mathrm{t}=-4.35, \mathrm{p}<0.001 ; \mathrm{t}=$ $-4.88, \mathrm{p}<0.001$ ). Concomitantly, the percentage contribution of $P$. amurensis to total abundance rapidly increased, reaching $95 \%$ during the latter half of 1988 (Fig. 6d). Interestingly, more than $70 \%$ of the non-P. amurensis individuals in the DWR samples and more than $20 \%$ in the REM samples collected between July and December 1988 represent the barnacle Balanus improvisus, occurring largely as individuals attached to the exposed ends of the shells of living $P$. amurensis.

Equally pronounced was the shift in biomass at the REM sampling site (Fig. 6e). The few quantitative measurements (e.g. Thompson \& Nichols 1981) and numerous unpublished observations reveal that mollusks dominate benthic biomass in the Suisun Bay area. Prior to 1987 Corbicula fluminea, represented by a few large specimens, dominated benthic biomass following wet 

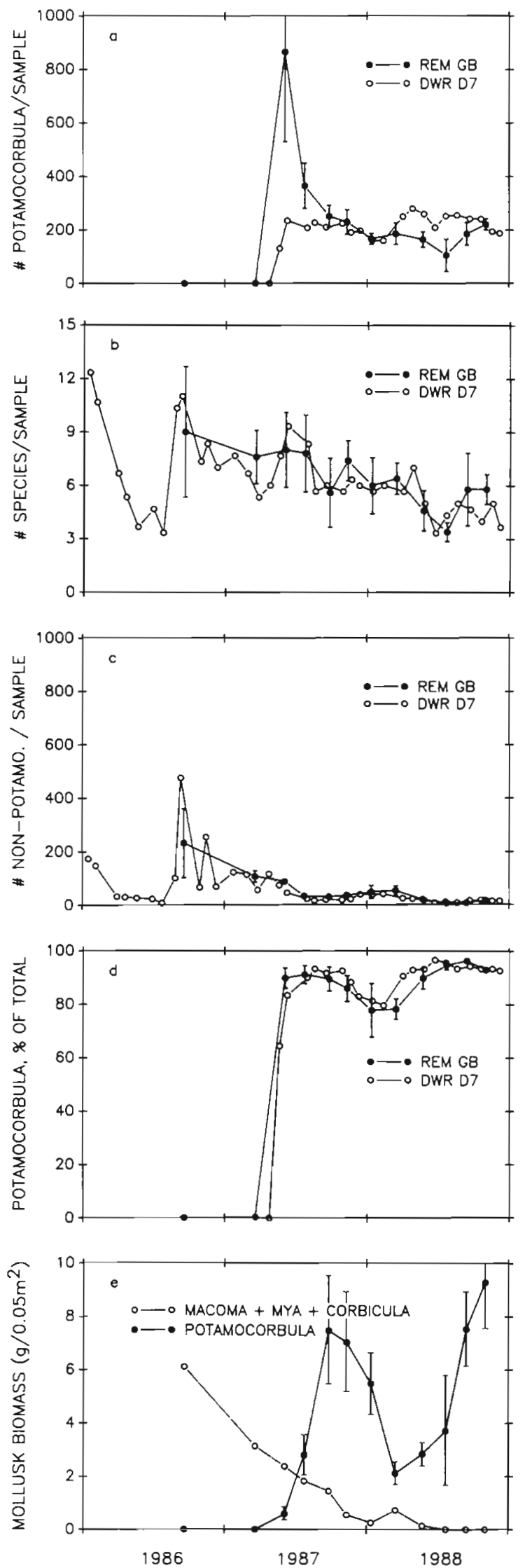

periods, e.g. in 1986, whereas Macoma balthica and Mya arenaria dominated during dry periods. Since its establishment in 1987, P. amurensis has contributed nearly all of the wet weight biomass (Fig. 6e).

\section{DISCUSSION}

We are not sure why the initial colonization and spread of Potamocorbula amurensis in northern San Francisco Bay were so successful, nor can we predict the long-term consequences that this introduction will have for the San Francisco Bay ecosystem. It is apparent, however, that the San Francisco Bay estuary was vulnerable to exploitation by this species.

Brown (1989) and Ehrlich (1986, 1989), among others (see Drake et al. 1989), suggest possible generalizations about biological invasions which might enable one to anticipate the success of an introduced species. These generalizations define a potentially successful invading species as one that (1) is relatively abundant and widely distributed where it is endemic, (2) can live in a broad range of habitat types and subsist on a wide variety of foods, (3) has a life stage that lends itself to transport by humans, and (4) invades an environment with a low diversity of native species or where the required niche is not fully occupied by native species. Given what we have learned about Potamocorbula amurensis, it is not surprising that it has been successful as an invading species, requiring only a mode of transport and a suitable host environment to become established in another part of the world.

Although we know little about environmental tolerances, food requirements, reproductive biology or its relationships with other species in its native Asia (Carlton et al. 1990), Patamocorbula amurensis is widely distributed there (Zhuang \& Cai 1983). Its present distribution in San Francisco Bay suggests that it is tolerant of a wide range of salinity and sediment types: it has since spread throughout the estuary and is found in all sediment types and water depths and in a salinity range from $<1$ to $>30 \%$ (Carlton et al. 1990). Given its eurytopicity and an opportunity (as larvae in ballast water (Carlton et al. 1990)] to be transported to and released in Suisun Bay in 1986, it is not surprising that

Fig. 6. (a) Potamocorbula amurensis abundance, (b) number of species, (c) number of non- $P$. amurensis individuals, (d) percentage of the $P$. amurensis contribution to total abundance at the DWR and REM sampling sites, and (e) wet weight biomass of mollusk species at the REM sampling site. All values are sample means $\left(\mathrm{n}_{\mathrm{DWR}}=3 ; \mathrm{n}_{\mathrm{REM}}=5\right)$. For clarity, error bars $( \pm 1$ standard deviation) are shown only for the REM abundance and $P$. amurensis wet weight data 
Potamocorbula amurensis could become established in San Francisco Bay. It is also probable, however, that the timing of the invasion, following a $2 \mathrm{yr}$ period of climatic extremes, was important to its initial success.

Prior to 1987, interannual patterns in benthic community structure in the Suisun Bay region of the estuary were apparently tightly coupled to interannual patterns in river inflow and the consequent effect on the salinity regime. During normal and wet years, freshand brackish-water species prevailed. During prolonged dry periods, estuarine species replaced them. The end of one of these dry periods (1984/85) was marked by an extreme, if short-lived flood event (Fig. 2) with the result that the freshwater-intolerant estuarine species populations were eliminated (Figs. $3 a, b$ and 4 ). High suspended sediment loads and the strong scouring and transport of bottom sediments during such a flood event may also have contributed to the disruption of the bottom community of the upper estuary. Thus, in mid-1986 when Potamocorbula amurensis was introduced, presumably via ship ballast water (Carlton et al. 1990), the Suisun Bay region was inhabited by a depauperate benthic community (Fig 6b). It is possible, therefore, that this species was initially successful because it exploited a naturally disturbed, sparsely occupied habitat rather than interjecting itself among and displacing existing species. If this is true, $P$. amurensis was acting, at least initially, as a colonizer rather than an invader (Bazzaz 1986).

The timing of its introduction, following a flood event, and its apparent tolerance of low salinity water (Carlton et al. 1990) guaranteed Potamocorbula amurensis many months to exploit the available space before the dry-period species would return. While a few (ca $50.05 \mathrm{~m}^{-2}$ ) juvenile Mya arenaria were collected at the study site during summer 1987, the simple relationship of $M$. arenaria abundance with the duration of the low-inflow period (Fig. 5) demonstrates that by mid-1987 insufficient time had elapsed to permit establishment of large populations of the dry-period species during the year of the new clam's arrival. Given the duration of the low-inflow period (since 1986), the dry-period community, containing a number of species approaching or exceeding that recorded during the $1976 / 77$ drought period (Fig. 3a; 11 to 13 species), should have been well established by summer 1988. Instead, there were only 3 to 5 species (Fig. 6b), and these were represented by only an occasional specimen (Fig. 6c). The near absence of the dry-period community in 1988 clearly demonstrates that the arrival of $P$. amurensis contributed to a complete change in benthic community dynamics in the area.

We can only guess about the mechanisms involved in the exclusion of the dry-period species. These species presumably colonize the Suisun Bay area by means of up-estuary transport of pelagic larvae or small juveniles in landward-flowing bottom currents during periods of low river inflow. Thus, the dry-period community species should have been in a position to colonize Suisun Bay again during 1988. There was some evidence that Mya arenaria recruits were available to settle at the site: occasional live $M$. arenaria juveniles ( 1 to $3 \mathrm{~mm}$ length) as well as numerous empty but still paired shells of the same size (potentially the same cohort) were found in the 1988 summer samples. We are left with the assumption that Potamocorbula amurensis somehow prevented these species from reestablishing their populations.

Preliminary laboratory evidence shows that Potamocorbula amurensis can consume nauplii of a local copepod (Eurytemora affinis) (W Kimmerer pers. comm.), bacteria (T. Hollibaugh pers. comm.), and phytoplankton (B. Cole \& J. K. T. pers. comm.). It is possible, therefore, that the clam can also feed on pelagic larvae of benthic invertebrates

Potamocorbula amurensis, in turn, has become a major component of the diet in several species of diving birds (P Hoffman, California Department of Fish and Game, pers. comm.) and bottom-feeding fish such as the sturgeon Acipenser transmontanus (K. Urquhart. California Department of Fish and Game, pers. comm.). There is no evidence, however, about the extent to which $P$. amurensis distribution and abundance is controlled by predators

As mentioned above, the dominance by Potamocorbula amurensis of the benthic community is not limited to this long-term study site. A sampling program begun in mid-1988 at 5 other sites in Suisun Bay, encompassing a range of habitats from soft, shallow subtidal mud to coarse, deep channel sand, is demonstrating the universal nature of this highly successful colonization (Thompson et al. unpubl.): $P$. amurensis is the overwhelming dominant at all sites in Suisun Bay, despite the persisting low river flow conditions. At the same time, it has spread to most other areas of San Francisco Bay, including into areas where large populations of numerous other introduced species are well established (Schemel et al. 1988, 1990). Ongoing field sampling in some of those areas will permit us to evaluate the success of this species as an invader, i.e. to determine how successful it is at inserting itself into and displacing the species in a pre-established community.

Acknowledgements. We thank Harlan Proctor of the California Department of Water Resources for providing unpublished data, Allan $Y$ Ota for providing assistance in collecting and processing the REM samples, and James T. Carlton, Edward B. Lyke, Thomas M. Niesen, and Charles H. Peterson for providing very helpful reviews of earlier versions of this report. 


\section{LITERATURE CITED}

Bazzaz, F. A. (1986). Life history of colonizing plants: some demographic, genetic, and physiological features. In: Mooney, H. A., Drake, J. A. (eds.) Ecology of biological invasions of North America anc. Hawaii. Ecological Studies 58. Springer-Verlag, New York, p. 96-110

Brown, J. H. (1989). Patterns, modes and extents of invasions by vertebrates. In: Drake, J. A., Mooney, H. A., di Castri, F., Groves, R. H., Kruger, F. J., Rejmanek, M., Williamson, M. (eds.) Biological invasions - a global perspective. Scientific Committee on Problems of the environment (SCOPE) 37. John Wiley, Chichester, p. 85-109

California Department of Water Resources (1989). Sacramento-San Joaquin Delta water quality surveillance program 1987 - monitoring results pursuant to conditions set forth in Delta Water Rights Decision 1485 , v. 3. Sacramento, California

Carlton, J. T., Thompson, J. K., Schemel, L. E., Nichols, F. H. (1990). Remarkable invasion of San Francisco Bay, (California, USA) by the Asian clam Potamocorbula amurensis. I. Introduction and dispersal. Mar. Ecol. Prog. Ser. 66: 81-94

Cloern, J. E., Nichols, F. H. (eds.) (1985). Temporal dynamics of an estuary: San Francisco Bay. Dr. W. Junk, Dordrecht, Netherlands

Drake, J. A., Mooney, H. A., di Castri, F., Groves, R. H., Kruger, F. J., Rejmanek, M., Williamson, M. (eds.) (1989). Biological invasions - a global perspective. Scientific Committee on Problems of the environment (SCOPE) 37. John Wiley, Chichester

Ehrlich, P. R. (1986). Which animals will invade? In: Mooney, H. A., Drake, J. A. (eds.) Ecology of biological invasions of North America and Hawaii. Ecological Studies 58. Springer-Verlag, New York, p. 79-95

Ehrlich, P. R. (1989). Attributes of invaders and the invading process: vertebrates. In: Drake, J. A., Mooney, H. A., di Castri, F., Groves, R. H., Kruger, F. J., Rejmanek, M., Williamson, $M$. (eds.) Biological invasions - a global perspective. Scientific Committee on Problems of the

This article was submitted to the editor environment (SCOPE) 37. John Wiley, Chichester, p. $315-328$

Elton, C. S. (1958). The ecology of invasions by animals and plants. Methuen, London

Mooney, H. A., Drake, J. A. (eds.) (1986). Ecology of biological invasions of North America and Hawaii. Ecological Studies 58. Springer-Verlag, New York

Nichols, F. H. (1985). Increased benthic grazing: an alternative explanation for low phytoplankton biomass in northern San Francisco Bay during the 1976-1977 drought. Estuar coast. Shelf Sci. 21: 379-388

Rosenblum, S. E., Niesen, T M. (1985). The spawning cycle of soft-shell clam, Mya arenaria, in San Francisco Bay. Fish. Bull. U.S. 83: 403-412

Schemel, L. E., Ota, A. Y., Harmon, J. G., Shay, J, M., Adorador, R. M. (1988). Benthic macrofauna and ancillary data for San Francisco Bay, California, March to November 1987. U. S. Geological Survey Open File Rep., Sacramento, Calif. 88-192

Schemel, L. E., Ota, A. Y., Harmon, J. G., Shay, J. M., Adorador, R. M. (1990). Benthic macrofauna and ancillary data for San Francisco Bay, California, January to November 1988. U. S. Geological Survey Open File Rep., Sacramento, Calif. 89-596

Simberloff, D. (1986). Introduced insects: a biogeographic and systematic perspective. In: Mooney, H. A., Drake, J. A. (eds.) Ecology of biological invasions of North America and Hawaii. Ecological Studies 58. Springer-Verlag, New York, p. 3-26

Storrs, P. N., Selleck, R. E., Pearson, E. A. (1963). A comprehensive study of San Francisco Bay, 1961-62. Univ. California Sanitary Engineering Research Lab. Rep., Berkeley, Calif. $63(3.4)$

Thompson, J. K., Nichols, F. H. (1981). Benthic macrofaunal biomass of San Francisco Bay, California: January/February and August 1973. U. S. Geological Survey Open File Rep. 81-1331

Zhuang, Q., Cai, Y. (1983). Studies on the Corbulidae (Bivalvia) off Chinese coasts. Trans. Chinese Soc. Malacology 1: $57-68$

Manuscript first received: January 29, 1990

Revised version accepted: June 1, 1990 